\title{
ANALISIS POTENSI KAWASAN RAWAN BANJIR KOTA KEPANJEN MENGGUNAKAN SISTEM INFORMASI GEOGRAFIS (SIG)
}

Agustinus Haryanto Pattiraja

Teknik Sipil, Universitas Katolik Widya Mandira-Kupang, gustiwre@gmail.com

\begin{tabular}{l} 
INFO ARTIKEL \\
\hline Riwayat Artikel: \\
Diterima: 04-1 1-2017 \\
Disetujui: 16-12-2017 \\
\hline
\end{tabular}

\section{Kata Kunci:}

Banjir

Debit Aliran

SIG

\begin{abstract}
ABSTRAK
Abstrak: Kota Kepanjen adalah Kota yang dipersiapkan menjadi Ibu Kota Kabupaten Malang, yang pemanfaatan lahan terus berkembangan dan dengan intensitas hujan yang cukup tinggi berdampak timbulnya genangan dan banjir. Penelitian ini bertujuan menganalisis potensi kawasan rawan banjir di Kota Kepanjen. Metode yang digunakan yaitu Sistem Informasi Geografis. Berdasarkan konsep analisis debit aliran Metode Rasional maka parameter penentu kawasan rawan banjir yang digunakan dalam kajian ini adalah intensitas hujan, kemiringan lereng, jenis tanah, dan tutupan lahan. Hasil analisis menunjukan bahwa kawasan yang berstatus sangat rawan pada kondisi eksisting dengan luasan sebesar 3,421 $\mathrm{Km}^{2}$ mengalami peningkatan seiring perubahan yang akan dilakukan terhadap Kota Kepanjen menjadi $4,54 \mathrm{Km}^{2}$, kawasan yang berstatus rawan pada kondisi eksisting dengan luasan sebesar $40,17 \mathrm{Km}^{2}$ mengalami peningkatan seiring perubahan yang akan dilakukan terhadap Kota Kepanjen menjadi $42,01 \mathrm{Km}^{2}$, kawasan yang berstatus aman pada kondisi eksisting dengan luasan sebesar $2,92 \mathrm{Km}^{2}$ mengalami penurunan seiring perubahan yang akan dilakukan terhadap Kota Kepanjen menjadi 0,22 $\mathrm{Km}^{2}$.
\end{abstract}

\begin{abstract}
Kepanjen is a city prepared to be the capital city of Malang in which the land use continues to develop and has high rainfall intensity leading to puddle and flood. This research aims to analyze the potential of high flood risk area in Kepanjen by employing Geographic Information System. Based on the Rational Method analysis concept of discharge, the parameter of high flood risk area in this research covered rainfall intensity, slope inclination, soil type, and land cover. The analysis results showed that the area with very vulnerable status under existing condition increased from $3.421 \mathrm{Km} 2$ to $4.54 \mathrm{Km} 2$ due to city development. While the area with vulnerable status under existing condition increased from $40.17 \mathrm{Km} 2$ to $42.01 \mathrm{Km} 2$ due to the development as well. On the other hand, the area considered safe under existing condition decreased from $2.92 \mathrm{Km} 2$ to $0.22 \mathrm{Km} 2$ because of the development performed.
\end{abstract}

\section{A. LATAR BELAKANG}

Banjir dan genangan merupakan peristiwa yang kerap terjadi di hampir semua kota di Indonesia terutama saat musim penghujan. Banjir terjadi karena meluapnya air sehingga menggenangi daerah yang biasanya tidak terkena air dengan melampaui batas yang ditolerir (Kustamar dan Yuwono, Endro, 2003) [3]. Hal yang paling mendasar menjadi penyebab banjir pada wilayah perkotaan di Indonesia adalah adanya perubahan tata guna lahan yang sangat pesat terutama pada daerah perkotaan yang sedang berkembang yang tanpa diimbangi dengan penyediaan fasilitas-fasilitas drainase yang cukup memadai sehingga sangat memungkinkan terjadinya banjir.

Kota Kepanjen dipersiapkan menjadi Ibu Kota Kabupaten Malang. Perubahan menjadi pusat Kota Kebupaten akan membawa dampak yang cukup signifikan terhadap pembangunan di wilayah Kota Kepanjen. Pengalihan fungsi lahan menjadi perkotaan cenderung ke arah penutupan tanah dengan bahanbahan semen yang tidak tembus air (impervous) sehingga mengakibatkan terganggunya keseimbangan hidrologi. Beberapa tahun terakhir Kota Kepanjen sering terjadi banjir akibat limpasan permukaan yang berlebihan. Wilayah Kota Kepanjen yang akan mengalami perubahan menjadi pusat Kota Kabupaten otomatis akan memperparah keadaan banjir yang ada jika tanpa solusi penanganan banjir yang tepat. Maka sebagai langkah awal untuk penanganan masalah banjir dan genangan yang terjadi perlu dilakukan analisis terhadap potensi kawasan rawan banjir untuk Kota Kepanjen tahun 2029 sesuai dengan Rencana Detail Tata Ruang Kawasan Perkotaan (RDTRK) seiring persiapan Kota Kepanjen menjadi pusat kota Kabupaten. Rumusan Masalah

$>$ Wilayah mana di Kota Kepanjen yang berpotensi rawan banjir untuk kondisi saat ini ?

$>$ Wilayah mana di Kota Kepanjen yang berpotensi rawan banjir akibat perkembangan kota seiring 
persiapan menjadi Ibu Kota Kabupaten Malang sesuai Rencana Detail Tata Ruang Kawasan Perkotaan (RDTRK) tahun 2029?

> Berapa besar peningkatan status akibat perkembangan kota seiring persiapan menjadi Ibu Kota Kabupaten Malang sesuai Rencana Detail Tata Ruang Kawasan Perkotaan (RDTRK) tahun 2029?

Dalam melakukan penelitian ini teori yang digunakan adalah:

\section{Limpasan Permukaan (Run Off)}

Limpasan permukaan merupakan gabungan antara aliran permukaan, aliran yang tertunda pada cekungan-cekungan, dan aliran bawah permukaan(Suripin, 2004) [6]. Untuk memperkirakan laju limpasan permukaan sering digunakan metode Rasional (Suripin, 2004) [6]. Rumus pada metode rasional diatas menjelaskan bahawa limpasan permukaan sangat dipengaruhi oleh koefisien pengaliran, intensitas hujan, dan luas daerah pengaliran. Koefisien pengaliran(C) merupakan nisbah antara puncak aliran permukaan terhadap intensitas hujan. Faktor utama yang mempengaruhi nilai $\mathrm{C}$ adalah laju infiltrasi tanah atau prosentase lahan kedap air, kemiringan lereng, tutupan lahan dan intensitas hujan. Intensitas hujan sangat tergantung pada laju infiltrasi. (Suripin, 2004) [6].

\section{Intensitas Hujan}

\section{Analisis Curah Hujan Rerata Daerah}

Analisis curah hujan rerata daerah digunakan metode Polygon Thiessen. Cara ini memberikan proporsi luasan daerah pengaruh pos penakar hujan (faktor pembobot) untuk mengakomodasi ketidakseragaman jarak. Daerah pengaruh dibentuk dengan menggambarkan garis-garis sumbu tegak lurus terhadap garis penghubung antara dua pos penakar terdekat .

\section{Analisis Curah Hujan Rancangan}

Analisis curah hujan rancangan dapat dilakukan dengan menggunakan metode Gumbel dan metode Log Person Type III yang kemudian dilakukan pengujian distribusi frekuensi untuk memastikan kebenaran distribusi yang telah kita lakukan.

\section{Intensitas Hujan}

Intensitas hujan yang digunakan dalam kajian yang dilakukan adalah rumus Mononobe.

\section{Koefisien Pengaliran Menurut Kemiringan Lereng}

Kemiringan lereng mempengaruhi terhadap kecepatan dan volume limpasan permukaan. Makin curam suatu lereng, maka prosentase kemiringan makin tinggi dan makin cepat limpasan permukaan. Selanjutnya dengan semakin singkatnya waktu untuk infiltrasi, maka volume limpasan permukaan makin besar.

\section{Koefisien Pengaliran Menurut Jenis Tanah}

Faktor jenis tanah, mempengaruhi terhadap koefisien aliran permukaan ( Subarkah,1978:54), ditinjau dari segi tektur yang sangat turut menentukan tata air dalam tanah, sehingga berpengaruh terhadap kapasitas infiltrasi yaitu kemampuan tanah untuk meloloskan air atau udara ke lapisan bawah profil tanah ( Suripin,2002:46 ) [6].

\section{Koefisien Pengaliran Menurut Penggunaan Lahan}

Aliran permukaan sangat dipengaruhi oleh penggunaan lahan yang dinyatakan dalam koefisien pengaliran (Suripin,2002:140). Secara umum semua jenis tanaman dapat mempengaruhi sifat tanah yang ada dibawahnya.

\section{Sistem Informasi Geografis}

Sistem Informasi Geografis atau yang disingkat dengan SIG merupakan suatu sistem yang berbasis komputer yang digunakan untuk menyimpan, memanipulasi dan analisis data secara geografis dan selanjutnya dapat dipakai sebagai bahan acuan dalam pengambilan suatu kepurusan/kesimpulan. (Stan Aronoff,1989:1). Ditinjau dari segi penyimpanan data, Sistem Informasi Geografis terdiri dari 2 jalur konseptual yaitu :

a. Model Data Raster (menggambarkan apa yang terjadi disetiap tempat).

b. Model Data Vektor (menggambarkan dimana saja segala sesuatu terjadi)

Sistem informasi geografis pada dasarnya menggunakan dua dimensi data, yaitu data geografis(spasial data) dan data atribut (non spasial data).

Secara garis besar SIG mempunyai 4 (empat) komponen yasitu;

a. Data input,

b. Management data,

c. Data manipulasi dan analisis, dan

d. Menampilkan produk SIG

Inti dari teknologi SIG adalah untuk mencari informasi yang berbasis spatial.

a. Pemasukan data

Data spasial dan data atribut

b. Penyimpanan dan pengambilan Data

c. Manipulasi dan analisis data

1) Fungsi Maintenance data spasial:

Format transformation antar data spasial, geometric transformation, tronsformasi antar proyeksi peta, conflation, edge , fungsi editing, dan line coordinate thinning.

2) Pengelolaan dan analisis data atribut

a) Kelompok fungsi ini digunakan untuk mengedit dan menganalisis data nonspasial. 
b) Analisis data atribut meliputi fungsi antara lain:

c) Fungsi Editing atribut, Fungsi Query atribut, dan Fungsi Statistik Atribut.

3) Anaslisis Data Spasial dan Atribut Secara Terintegrasi

1). Penyajian Informasi

Hasil suatu proses SIG akan disajikan dalam bentuk peta, tabel dan gambar-gambar grafik yang sesuai dengan kebutuhan. Penyajian informasi dalam studi ini merupakan akhir dari suatu proses SIG, diharapkan dari penyajian ini penyaji SIG ini, dapat diambil suatu kesimpulan/keputusan yang melakukan langkah selanjutnya.

\section{B. METODE PENELITIAN}

Pada penelitian ini analisis data menggunakan teknologi Sistem Informasi Geografis (SIG) dengan memanfaatkan program bantuan yaitu ArcView 3.3 untuk mempermudah analisis.

Data sekunder yang didapatkan berupa peta jenis tanah, peta penggunaan lahan, peta kemiringan lereng, dan data hujan yang dianalisis menjadi sebaran intensitas hujan kemudian diolah dengan bantuan program AutoCad dan ArcView 3.3. Sehingga menjadi peta dengan masing-masing layer yang berisi informasi kelas kerawanan banjir.

Berdasarkan studi pustaka yang dilakukan maka kelas kerentanan terhadap bahaya banjir untuk setiap layer atau variable dapat dilihat seperti pada table1,2,3,dan 4.

TABEL 1. NILAI KELAS RAWAN BANJIR UNTUK JENIS KEMIRINGAN LERENG

\begin{tabular}{|c|l|c|c|c|}
\hline No & \multicolumn{1}{|c|}{$\begin{array}{c}\text { Tipe } \\
\text { Permukaan } \\
\text { Tanah }\end{array}$} & $\begin{array}{c}\text { Nilai } \\
\text { C }\end{array}$ & $\begin{array}{c}\text { Kelas } \\
\text { Rawan } \\
\text { Banjir }\end{array}$ & $\begin{array}{c}\text { Bobot } \\
\text { Nilai } \\
\text { Rawan } \\
\text { Banjir }\end{array}$ \\
\hline 1 & $\begin{array}{l}\text { Daerah yang } \\
\text { curam (40\% - } \\
\text { keatas) }\end{array}$ & 0.85 & $\begin{array}{c}\text { Sangat } \\
\text { Rawan }\end{array}$ & 1 \\
\hline 2 & $\begin{array}{l}\text { Daerah tersier } \\
\text { (15-40 \%) }\end{array}$ & 0.75 & Rawan & 2 \\
\hline 3 & $\begin{array}{l}\text { Daerah yang } \\
\text { bergelombang } \\
(2-15 \%)\end{array}$ & 0.65 & Aman & 3 \\
\hline 4 & $\begin{array}{l}\text { Daerah datar } \\
\text { (0-2 \%) }\end{array}$ & 0.55 & Sangat & 4 \\
\hline
\end{tabular}

TABEL 2. NILAI KELAS RAWAN BANJIR UNTUK JENIS TANAH

\begin{tabular}{|c|l|c|c|c|}
\hline No & \multicolumn{1}{|c|}{$\begin{array}{c}\text { Tektur } \\
\text { Tanah }\end{array}$} & $\begin{array}{c}\text { Nilai } \\
\text { C }\end{array}$ & $\begin{array}{c}\text { Kelas } \\
\text { Rawan } \\
\text { Banjir }\end{array}$ & $\begin{array}{c}\text { Bobot } \\
\text { Nilai } \\
\text { Rawan } \\
\text { Banjir }\end{array}$ \\
\hline 1 & $\begin{array}{l}\text { Liat berpasir } \\
\text { s/d lempung } \\
\text { berpasir (very } \\
\text { heavy) }\end{array}$ & 0.60 & $\begin{array}{l}\text { Sangat } \\
\text { Rawan }\end{array}$ & 1 \\
\hline 2 & $\begin{array}{l}\text { Lempung } \\
\text { berdebun s/d } \\
\text { lempung }\end{array}$ & 0.50 & Rawan & 2 \\
\hline
\end{tabular}

\begin{tabular}{|c|c|c|c|c|}
\hline & berliat (heavy) & & & \\
\hline 3 & Liat (medium) & 0.55 & Aman & 3 \\
\hline
\end{tabular}

TABEL 3. NILAI KELAS RAWAN BANJIR UNTUK TUTUPAN LAHAN

\begin{tabular}{|c|c|c|c|c|}
\hline No & Nilai C & Kriteria & $\begin{array}{c}\text { Kelas } \\
\text { Rawan } \\
\text { Banjir }\end{array}$ & $\begin{array}{c}\text { Bobot } \\
\text { Nilai } \\
\text { Rawan } \\
\text { Banjir }\end{array}$ \\
\hline 1 & C $>0.6$ & Tinggi & $\begin{array}{c}\text { Sangat } \\
\text { Rawan }\end{array}$ & 1 \\
\hline 2 & $0.6-0.4$ & Sedang & Rawan & 2 \\
\hline 3 & $0.4<\mathrm{C}$ & Rendah & Aman & 3 \\
\hline
\end{tabular}

TABEL 4. NILAI KELAS RAWAN BANJIR UNTUK INTENSITAS HUJAN

\begin{tabular}{|c|l|c|c|}
\hline No & \multicolumn{1}{|c|}{$\begin{array}{c}\text { Intensitas Hujan } \\
\text { Harian }\end{array}$} & $\begin{array}{c}\text { Kelas } \\
\text { Rawan } \\
\text { Banjir }\end{array}$ & $\begin{array}{c}\text { Bobot } \\
\text { Nilai } \\
\text { Rawan } \\
\text { Banjir }\end{array}$ \\
\hline 1 & $100 \mathrm{~mm} / \mathrm{hari}>$ & Tinggi & 1 \\
\hline 2 & $\begin{array}{l}20 \mathrm{~mm} / \mathrm{hari}-100 \\
\mathrm{~mm} / \mathrm{hari}\end{array}$ & Sedang & 2 \\
\hline 3 & $<20 \mathrm{~mm} / \mathrm{hari}$ & Rendah & 3 \\
\hline
\end{tabular}

Analisis kawasan rawan banjir dalam kajian yang dilakukan adalah dengan bantuan konsep SIG. Konsep SIG yang digunakan dalam kajian yang dilakukan yaitu berupa fungsi overlay. Overlay merupakan proses penggabungan dua layer atau lebih untuk membentuk satu layer baru, dengan mengintegrasikan informasi (spasial dan atribut) dari berbagai sumber (layer) untuk pengambilan keputusan.

TABEL 5. KRITERIA KAWASAN RAWAN BANJIR

\begin{tabular}{|c|c|c|}
\hline No & $\begin{array}{c}\text { Kriteria Kawasan } \\
\text { Rawan Banjir }\end{array}$ & $\begin{array}{c}\text { Bobot Nilai Rawan } \\
\text { Banjir }\end{array}$ \\
\hline 1 & Sangat rawan & $4-6,25$ \\
\hline 2 & Rawan & $6,25-8,5$ \\
\hline 3 & Aman & $8,5-10,75$ \\
\hline 4 & Sangat Aman & $10,75-13$ \\
\hline
\end{tabular}

\section{ANALISIS DAN PEMBAHASAN}

Berdasarkan kriteria yang telah dibuat maka data-data yang ada kemudian disesuaikan dengan batasan wilayah studi yaitu Kota Kepanjen. Sehingga peta tersebut menjadi peta tematik wilayah Kota Kepanjen dengan masing-masing informasi yaitu kemiringan lereng, jenis tanah, penggunaan lahan dan intensitas hujan yaitu sebagai berikut. 


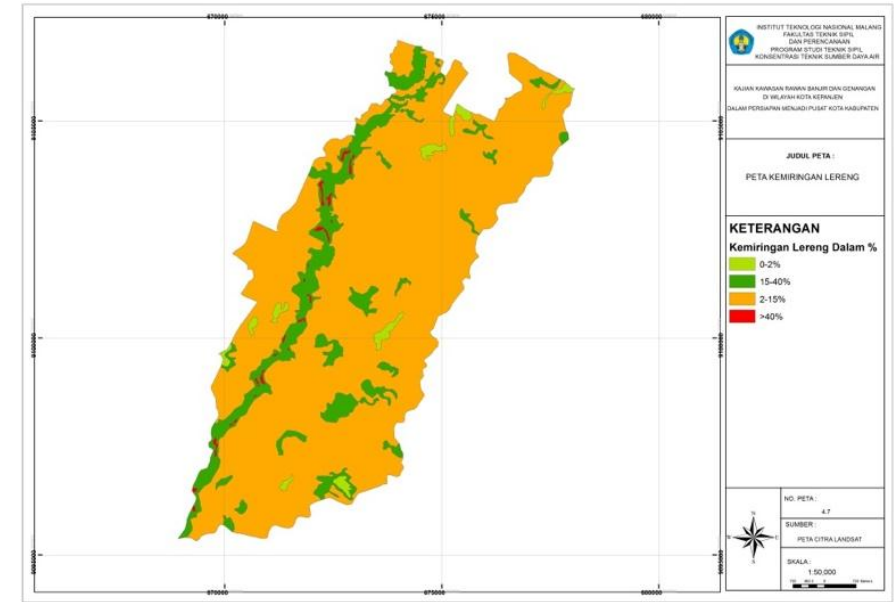

Gambar 1. Peta Kemiringan Lereng

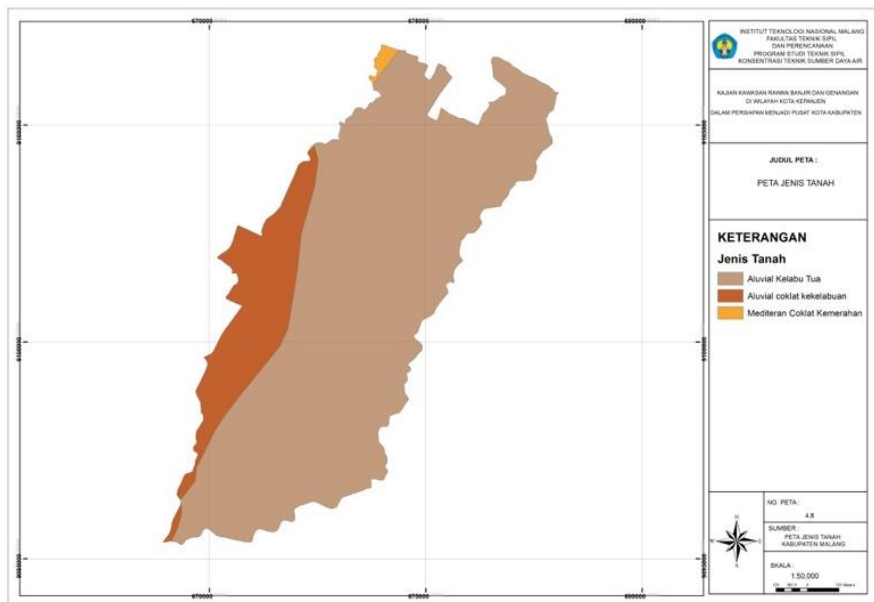

Gambar 2. Peta Kemiringan Jenis Tanah

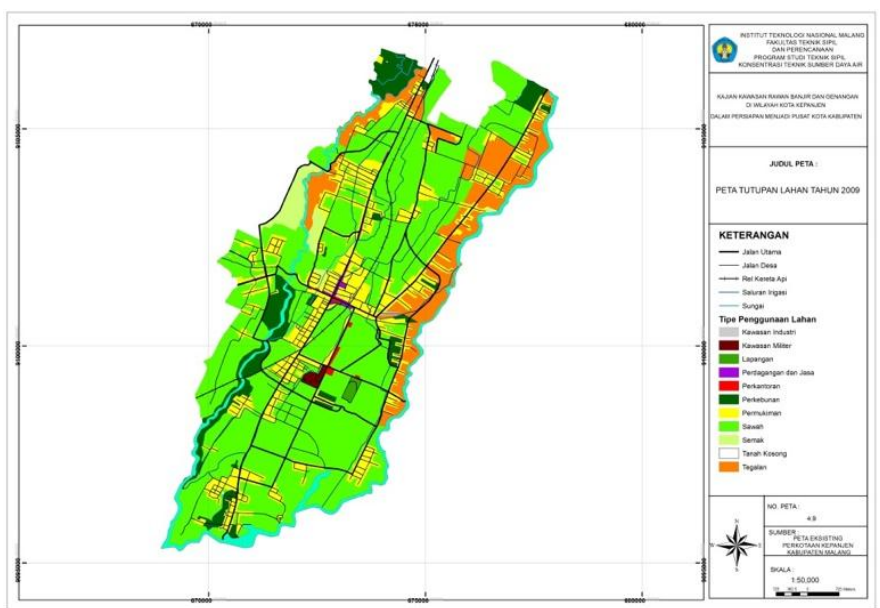

Gambar 3. Peta Penggunaan Lahan Eksisting

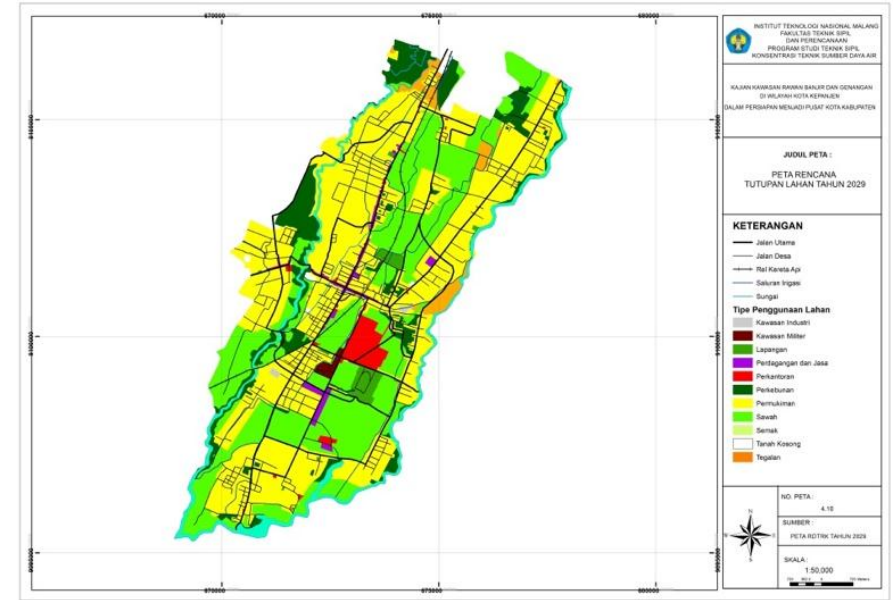

Gambar 4. Peta Penggunaan Lahan Sesuai RDTRK 2029

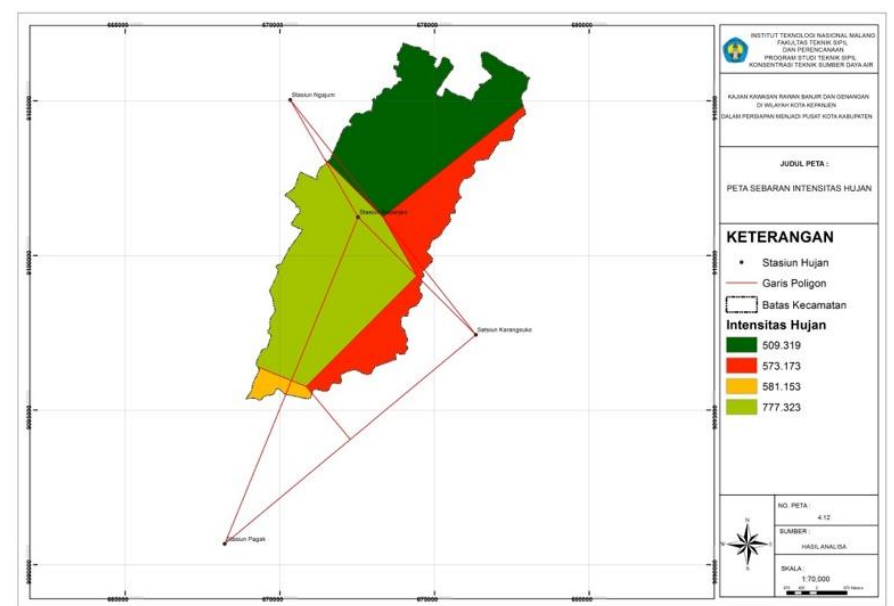

Gambar 5. Peta Sebaran Intensitas Hujan

Semua peta kemudian dioverlay/ ditumpuk dengan bantuan program ArcView sehingga menghasilkan besaran angka yang menunjukan kerentanan kawasan terhadap bahaya banjir yang disesuaikan dengan kriteria yang telah dibuat. Maka hasil analisis adalah sebagai berikut :

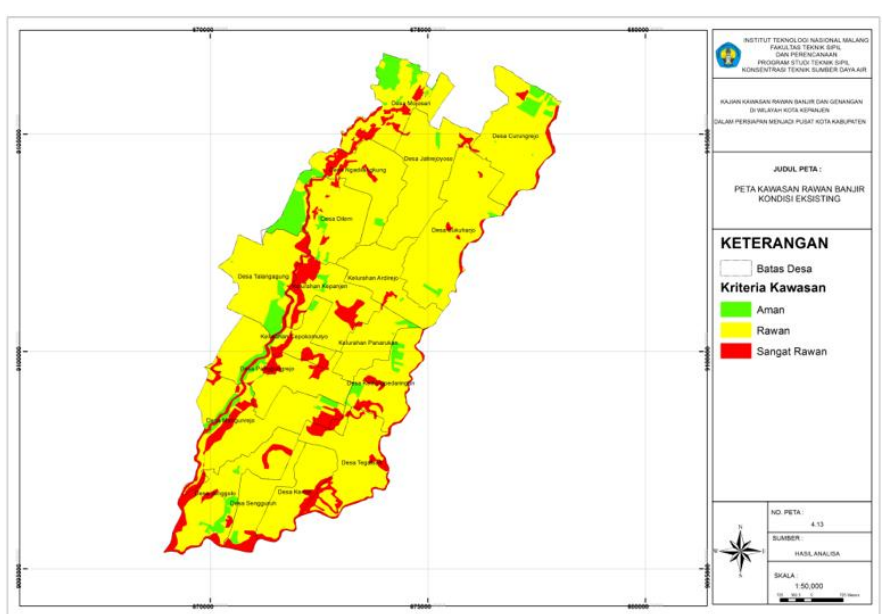

Gambar 6. Peta Kawasan Rawan Banjir Kota Kepanjen Pada Kondisi Eksisting 


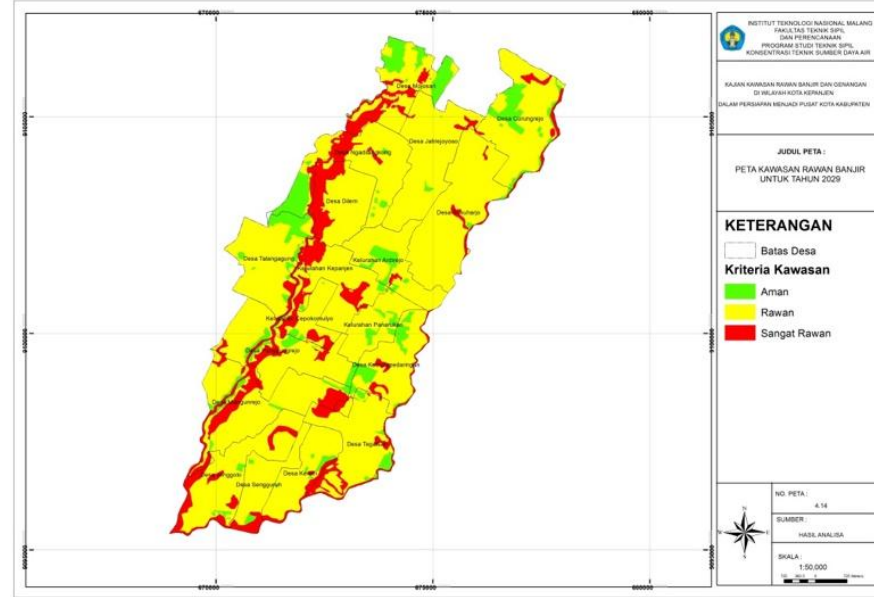

Gambar 7. Peta Kawasan Rawan Banjir Kota Kepanjen Pada Kondisi Sesuai RDTRK Tahun 2029

Berdasarkan hasil analisis yang dilakukan kemudian dibuatkan besaran presentase luasan kriteria potensi rawan banjir, yaitu sebagai berikut :

Tabel 8. Presentase Luas Kriteria Kwasan Rawan Banjir.

\begin{tabular}{|c|c|c|c|c|c|c|c|}
\hline \multirow{2}{*}{ No } & \multirow{2}{*}{ Nama Desa/Kelurahan } & \multicolumn{6}{|c|}{ Luas Kriteria Kawasan (\%) } \\
\cline { 3 - 8 } & & \multicolumn{3}{|c|}{ Eksisting 2009 } & \multicolumn{3}{c|}{ RDTRK 2029 } \\
\cline { 3 - 8 } & Desa Curungrejo & 1.3 & 90.5 & 8.1 & 3.3 & 96.5 & 0.2 \\
\hline 2 & Desa Dilem & 3.7 & 92.1 & 4.2 & 26.4 & 73.6 & 0.0 \\
\hline 3 & Desa Jatirejoyoso & 1.6 & 97.3 & 1.1 & 2.1 & 97.1 & 0.7 \\
\hline 4 & Desa Jenggolo & 14.0 & 79.0 & 7.0 & 14.8 & 85.2 & 0.0 \\
\hline 5 & Desa Kedungpedaringan & 10.3 & 80.3 & 9.4 & 7.3 & 92.4 & 0.2 \\
\hline 6 & Desa Kemiri & 3.1 & 96.8 & 0.1 & 2.1 & 97.5 & 0.4 \\
\hline 7 & Desa Mengunrejo & 15.0 & 79.0 & 6.0 & 18.1 & 81.7 & 0.1 \\
\hline 8 & Desa Mojosari & 13.0 & 68.9 & 18.1 & 20.1 & 79.0 & 0.8 \\
\hline 9 & Desa Ngadilangkung & 6.9 & 72.1 & 21.0 & 10.2 & 89.7 & 0.1 \\
\hline 10 & Desa Penggungrejo & 0.7 & 93.5 & 5.9 & 8.9 & 91.0 & 0.1 \\
\hline 11 & Desa Sengguruh & 0.0 & 96.9 & 3.1 & 0.0 & 100.0 & 0.0 \\
\hline 12 & Desa Sukoharjo & 1.1 & 97.5 & 1.4 & 2.1 & 97.4 & 0.4 \\
\hline 13 & Desa Talangagung & 3.1 & 86.0 & 10.9 & 1.8 & 98.2 & 0.0 \\
\hline 14 & Desa Tegalsari & 12.9 & 87.1 & 0.0 & 11.2 & 84.3 & 4.5 \\
\hline 15 & Kelurahan Ardirejo & 1.9 & 97.8 & 0.2 & 1.7 & 98.3 & 0.0 \\
\hline 16 & Kelurahan Cepokomulyo & 20.9 & 74.4 & 4.8 & 23.3 & 76.6 & 0.1 \\
\hline 17 & Kelurahan Kepanjen & 25.0 & 72.9 & 2.2 & 22.8 & 77.2 & 0.0 \\
\hline 18 & Kelurahan Panarukan & 1.0 & 95.4 & 3.5 & 0.9 & 98.9 & 0.1 \\
\hline
\end{tabular}

Hasil kajian menunjukan bahwa kawasan yang berstatus sangat rawan pada kondisi eksisting dengan luasan sebesar 3,421 $\mathrm{Km}^{2}$ mengalami peningkatan seiring perubahan yang akan dilakukan terhadap Kota Kepanjen menjadi 4,54 $\mathrm{Km}^{2}$, kawasan yang berstatus rawan pada kondisi eksisting dengan luasan sebesar 40,17 $\mathrm{Km}^{2}$ mengalami peningkatan seiring perubahan yang akan dilakukan terhadap Kota Kepanjen menjadi 42,01 $\mathrm{Km}^{2}$, kawasan yang berstatus aman pada kondisi eksisting dengan luasan sebesar $2,92 \mathrm{Km}^{2}$ mengalami penurunan seiring perubahan yang akan dilakukan terhadap Kota Kepanjen menjadi 0,22 $\mathrm{Km}^{2}$.

\section{KESIMPULAN}

Wilayah yang paling berpotensi banjir untuk kondisi saat ini adalah wilayah Kelurahan Kepanjen dengan luasan kawasan berstatus sangat rawan mencapai $0,62 \mathrm{Km}^{2}$ atau $24,95 \%$ dari luas keseluruhan wilayah $2,48 \mathrm{Km}^{2}$. Hal ini dikarenakan pada kawasan Kelurahan Kepanjen untuk kondisi saat ini hampir seluruh wilayahnya merupakan kawasan permukiman.

> Wilayah yang paling berpotensi banjir untuk kondisi yang akan datang sesuai perubahan yang akan terjadi adalah wilayah Desa Dilem dengan luasan kawasan berstatus sangat rawan mencapai $0,57 \mathrm{Km}^{2}$ atau $26,42 \%$ dari luas keseluruhan wilayah $2,19 \mathrm{Km}^{2}$. Hal ini dikarenakan pada kawasan Desa Dilem seiring perubahan yang akan terjadi di Kota Kepanjen dalam persiapan Kota Kepanjen menjadi pusat Kota Kabupaten mengalami perkembangan yang cukup pesat dimana terjadinya peningkatan kawasan permukiman.

> Peningkatan yang terjadi terhadap luasan masing-masing kriteria kawasan adalah sebagai berikut ; luasan kawasan dengan kriteria sangat rawan mengalami peningkatan sebesar 2,39\% yaitu dari kondisi eksisting $7,31 \%$ dari luas keseluruhan wilayah meningkat menjadi 9,71\% , luasan kawasan dengan kriteria rawan mengalami peningkatan sebesar 3,91\% yaitu dari kondisi eksiting 85,89 \% dari luas keseluruhan wilayah meningkat menjadi $89,80 \%$, dan luasan kawasan dengan kriteria aman mangalami penurunan sebesar $5,77 \%$ yaitu dari kondisi eksisting 6,25 \% dari luas keseluruhan wilayah menurun menjadi $0,48 \%$.

\section{UCAPAN TERIMA KASIH}

Penulis mengucapkan terima kasih kepada semua pihak yang telah membantu penelitian ini yaitu rekan-rekan dosen Teknik Sipil Universitas Widya Mandira Kupang dan Dr. Kustamar., MT (Dosen Teknik Sipil ITN Malang.

\section{DAFTAR RUJUKAN}

[1] Badan Perencanaan Daerah Kabupaten Malang. Jenis Tanah Kabupaten Malang. 2008

[2] Kodoatiei, Robert J. dan Sjarief, Roestam, 2006. Pengelolaan Sumber Daya Air Terpadu. ANDI, Yogyakarta.

[3] Kustamar dan Yuwono, Endro, 2003. Prediksi Daerah Rawan Longsor Dan Sungai Rawan Banjir Kota Batu. Jejak Kita. Yogyakarta

[4] Kustamar, 2008. Konsep, Stategi, dan Contoh Pemodelan Hidrologi Daerah Aliran Sungai. Universitas Negri Malang. Malang

[5] Soenarmo, Hartati, Sri., Penginderaan Jauh dan Pengenalan Sistem Informasi Geografis Untuk Bidang Ilmu Kebumian. ITB Bandung, Bandung.

[6] Suripin. 2004. Sistem Drainase Perkotaan Yang Berkelanjutan. ANDI, Yogyakarta 
6 | JPe | Vol. 3, No. 1, Februari 2018, hal 1-.6

\section{PROFIL PENULIS UTAMA}

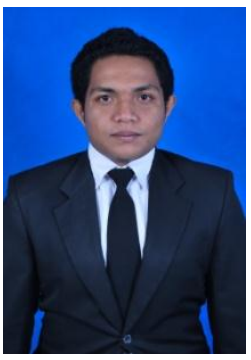

Nama lengkap penulis Agustinus Haryanto Pattiraja, lahir di Ende (Flores-NTT) tanggal 2 Agustus 1990. Pendidikan SMA Negri 1 Maumere tamat 2008, mendapat gelar Sarjana Teknik dari Institut Teknologi Nasional Malang tahun 2012, dan gelar Magister Teknik dari Institut Teknologi Sepuluh Nopember Surabaya pada tahun 2015. Pada tahun 2015 ikut mempublikasikan tulisan dalam Seminar Nasional Teknik Sipil XI yang diselenggarakan Program Studi Pascasarjana Teknik Sipil ITS Surabaya dengan judul Analisis Hidraulik Aliran Pada Kolam Olak Berpenampang Majemuk. 